\title{
An assessment of students' perception and self-efficacy towards mobile learning: A case of University of Zululand
}

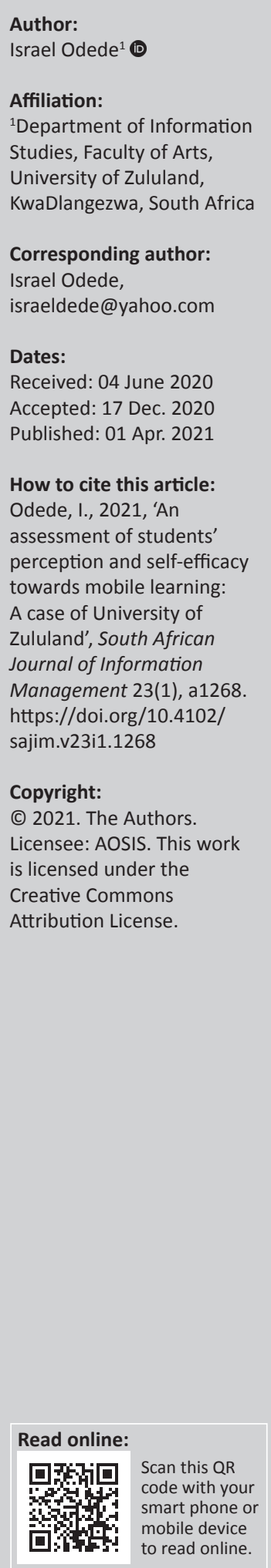

Background: Mobile learning (m-learning) has been recognised as an essential educational technology component in higher education. The use of mobile devices and the prospect to learn irrespective of time and place make mobile learning an important tool for students. Many studies have been conducted because of the importance of m-learning in advancing teaching and learning but few published scholarly studies have focused on perception and mobile self-efficacy.

Objectives: The study's objective is to assess students' perception and self-efficacy towards mobile learning at the University of Zululand.

Method: The study adopted a descriptive survey method and a stratified random sampling technique was used to select 200 undergraduate students from the four faculties for the study. Data were collected using questionnaire. Statistical tools such as frequency count and simple percentage were employed in analysing the collected data.

Results: WhatsApp, Facebook and YouTube are the top three social media applications mostly used by the students. Results showed that the students have positive perceptions towards $\mathrm{m}$-learning and possess the confidence needed in using m-learning solutions.

Conclusion: Perception and mobile self-efficacy towards m-learning technology are important factors that help in determining whether or not students are ready to use m-learning. Hence, this study focuses on investigating the perception and self-efficacy of undergraduate students at the University of Zululand towards m-learning. Therefore, the study concludes that the University management fully integrates m-learning solutions to its academic programmes to enhance the quality of teaching and learning.

Keywords: assessment; students; perception; self-efficacy; m-learning; University of Zululand.

\section{Introduction}

Mobile learning popularly known as m-learning has become a new educational paradigm that is popular in recent years especially at institutions of higher learning. The concept of m-learning is made possible via rapid development in mobile technology. According to Hwang and Tsai (2011), 'm-learning is described as using mobile technologies to facilitate learning'. Mobile learning (m-learning) is defined as a 'form of e-learning that specifically uses mobile devices to integrate with ubiquitous computing technologies to deliver learning contents and supports' (Hwang \& Chang 2011). Hwang and Chang's (2011) definition is adopted for this study as it contained the researcher's view of m-learning. Mobile learning makes it possible for students to communicate, interact and behave amongst each other with the aid of mobile devices. Mobile devices that allow m-learning include smartphones, MP3 and MP4 devices, personal digital assistants (PDAs), tablet computers and other portable devices. Generally, m-learning can be viewed as any form of learning that takes place when mediated through a mobile device (Hwang \& Tsai 2011). In an m-learning setting, knowledge can be conveyed via portable devices. The use of m-learning devices have changed the way students learn as it reinforces communication amongst teachers and students, supports several multimedia tools and inspires individual learning (Cromptona \& Burkeb 2018). Mobile learning places emphasis on the fact that the teaching and learning process can take place without being constrained by time and location (Al-Hunaiyyan, Alhajri \& Al-Sharhan 2018). It is said to increase students' motivations and achievement (Hwang \& Chang 2011; Liaw, Hatala \& Huang 2010). In addition, it allows 'learners to have access to learning contents such as learning materials and conduct personalised curriculum sequencing according to their learning needs' (Hwang \& Chang 2011). Hence, 'mobile devices technologies are 
becoming more capable of supporting communication services and managing learning contents' (Sarrab 2015).

Mobile learning permits educators to 'generate online learning solutions for learners, which can be used anywhere and anytime as necessary in order to attain results that cannot be attained with other existing educational models' (Jou et al. 2016). The importance of $m$-learning cannot be over emphasised as it affords learners with the aptitude to communicate amongst themselves to complete tasks and activities towards accomplishing learning objectives (Cheon et al. 2012). 'Mobilelearning is a critical educational component of higher education that allows students to learn, collaborate and share their ideas with the help of internet and technology development' (Hamidi \& Chavoshi 2018). Thus, mobile devices are becoming more capable of supporting communication services and managing learning contents. Mobile learning can further 'extend the flexibility of e-learning regardless of learners' location using handheld mobile devices through wireless technologies' (Hung \& Zhang 2012). Essentially, m-learning plays an exceptionally central role in the field of education where it can make substantial contributions to learners' learning performance. 'Mobile learning has the potential to become main stream in the foreseeable future' (Alzahrani, Alalwan \& Sarrab 2014; Tana \& Aib 2011). The perception and self-efficacy of $\mathrm{m}$-learning are important factors in determining that learners and educators are prepared to accept or reject it. Self-efficacy is a multidimensional construct that indicates the ways people feel, think and behave in certain situations. Students' self-efficacy plays a substantial role in their decision to adopt m-learning. According to Yorganci (2017), 'selfefficacy is one of the significant factors for students' acceptance of m-learning technology and m-learning usage'. Essentialy (Hung \& Zhang 2012):

$[M]$-learning is based on the use of mobile devices anywhere at any time and the prevalent use of portable technologies makes it easier for learners to learn when and where they intend to access the learning materials. (p. 5)

In this study, m-learning refers to the use of mobile devices for learning, which integrates with ubiquitous computing technologies to support learners' learning activities.

\section{Literature review}

Mobile learning has been a 'popular research topic in recent years because of the increasing penetration rate of mobile devices globally' (Al-Emran, Elsherif \& Shaalan 2016; AlHunaiyyan et al. 2018; Chen et al. 2015; Hung \& Zhang 2012). New mobile devices and technologies have changed the way students access educational resources, communicate and socialise with each other, adding value to m-learning (Zidoun et al. 2016). Chen et al. (2015) pointed out that 'mobile platforms allow learners to collaborate with their classmates, search information, find and search locations'. Educators in universities and schools have explored the intentions of using m-learning compared with traditional learning methods (Al-Hunaiyyan et al. 2018):
Educational institutions around the world have started to use mobile technology because the value of deploying mobile technologies in the service of teaching and learning seems to be both self-evident and unavoidable. (p. 280)

This has greatly changed the nature of higher education as it increased educational opportunities and has unlocked the approach to new teaching/learning methodologies because of the speedy development of mobile computing devices and Internet resources (Liaw et al. 2010). According to Moreira et al. (2018), 'mobile learning is a type of electronic learning, which is implemented through mobile technologies such as personal digital assistants (PDA), cell phones, audio players, and electronic books and others'. Mobile devices have broadened the availability of educational materials through decreased cost and increased flexibility.

However, implementing m-learning entails a high level of commitment from both lecturers and students; otherwise, it might neither be achievable nor effective. Moreover, it is also imperative to establish students' perception and mobile selfefficacy before implementing m-learning.

Studies have shown that m-learning has a significant impact on teaching and learning (Al-Hunaiyyan et al. 2018; Cromptona \& Burkeb 2018; Erkollar \& Oberer 2012; Jaradat 2014) as it provides learners with an opportunity to change from existing learning approaches to a more flexible approach in dealing with learning experiences. Mobile learning has grown popularity amongst students and educators for accomplishment in a more flexible and comfortable way. Thus, 'many researchers and educators are currently exploring the potential of mobile devices in supporting the learning process' (Al-Shehri 2012). Some studies (such as Chaka \& Govender 2017; Keengwe \& Maxfield 2015) have disputed that m-learning is an extension of e-learning, but that it differs in the sense that it uses mobile devices rather than computers as a medium. Various universities worldwide have integrated m-learning for delivering lessons anytime anywhere in different ways (Enriquez 2010):

In Canada College and San Francisco State University (SFSU), Interactive Learning Network (ILN) model which involves both tablet PCs and wireless technology has been implemented for pre-and post-tests to assess the students' performance. (p. 79)

\section{Erkollar and Oberer (2012):}

$[A]$ ddressed the integration of m-learning with Geographic Information System (GIS) module in a pilot course within a Turkish university where each student has been provided with a tablet device equipped by Google and Hangout Apps in order to facilitate the students' communication. (n.p.)

In addition, mobile phones have been used as a learning tool for teaching French language at Princess Nora University, Saudi Arabia (Jaradat 2014). De Pablos, Tennyson and Lytras (2015) conducted two studies at the American University of Sharjah, UAE, for undergraduates' students in order to examine the usage of iPads during one semester in 
Mathematics course. Tsai, Tsai and Hwang (2010) 'developed an instrument to measure students' attitude and self-efficacy using the Personal Digital Assistant (PDA) in a ubiquitous learning (U-learning) environment'.

Findings based on responses by 414 grade 3 and 6 pupils showed that the respondents had a positive mobile selfefficacy in m-learning environment. 'A cross-sectional study by Kenny et al. (2010) amongst nursing students and staff also showed that the respondents had a very high level of mobile self-efficacy'.

Studies have shown 'that mobile self-efficacy and students' perception are important variables in the new learning environment involving information technologies' (Al-Emran et al. 2016; Al-Hunaiyyan et al. 2018; Mahat, Ayub \& Wong 2012). A study by Al-Hunaiyyan et al. (2018) on 'perceptions and challenges of mobile learning in Kuwait revealed that students and instructors have positive opinions about m-learning'. The results strongly suggest that 'most of the students and instructors perceived mobile learning as attractive learning tool because it allows them the freedom to learn whenever and wherever they want'. Therefore, the value of mobility in m-learning is appreciated by students and instructors.

Besides students' perception of m-learning, students' mobile self-efficacy is also an imperative factor to consider in the discussion on m-learning. A study conducted by Yorganci (2017) investigated students' self-efficacy and attitudes towards the use of m-learning. The results revealed that 'students' level of self-efficacy, in general, had moderate and the majority of students had positive attitudes towards using m-learning'. Studies by Menekse, Anwar and Purzer (2018) and Zheng, Li and Zheng (2017) show that 'students have positive mobile self-efficacy in an m-learning environment'. Lee and Mendlinger (2011:244) defined 'selfefficacy as an individual's belief that one has the ability to perform a particular behavior or task'. Self-efficacy defines persistency and shows how tough one could be in difficult situations with the intention to successfully complete such an activity. Hence, individuals possessing self-efficacy perception expect to succeed and will persevere in an activity to ensure successful completion. On the contrary, 'individuals with low self-efficacy perception anticipate failure and are less likely to persist doing challenging activities' (Sharma \& Nasa 2014:58). Self-efficacy is not a measure of a specific skill but the extent to which individuals believe they can perform by using their skills. Thus, selfefficacy does not reflect the diversity of skills possessed but the confidence to apply those skills in a given situation, which is highly needed when using technological devices such as m-learning device. Adopting m-learning requires mobile self-efficacy from both lecturers and students. Some proponents of m-learning therefore believe that learners are likely to use technology when perceived to be useful to them and possess the required technological skills and confidence. These are arguments that require further exploration because they can possibly be critical factors constraining the application of mobile technologies in developing country contexts in m-learning. Such factor is not limited to learners only but educators. According to Kukulska-Hulme (2014), emerging technologies pose many practical and ethical challenges to students and educators. Recent research reports that some educators see mobile technologies as disruptive tools that are not useful and increase distraction from learning (Al-Jarrah, Talafhah \& Al-Jarrah 2019). Given such challenges on mobile technology use, its application in higher education especially in the developing world remains problematic despite their adoption being a continuous trend. Therefore, it is important for researchers to investigate these variables before implement a learning process that involves the use of mobile devices for learning purposes. Hence, this study is set out to assess students' perception and self-efficacy towards m-learning at the University of Zululand.

\section{Theoretical framework for the study}

The present study adopted the theory of planned behaviour (TPB). The TPB was developed by Icek Ajzen as an attempt to predict human behaviour (Ajjan \& Hartshorne 2008). The TPB is fundamentally an extension of the theory of reasoned action (TRA). 'The theory emerged based on the limitations of the TRA in dealing with behaviour over which people have incomplete volitional control and includes measures of controlled belief and perceived behavioural control' (Li 2010). TRA is used to 'predict an individual's behaviour only in a real voluntary situation, not in a mandatory context' (Li 2010). TPB extends TRA to consider the mandatory situation, adding a new construct of perceived behavioural control. Hence, the TPB comprised of six constructs that collectively represent a person's actual control over the behaviour and intention to use technologies. The constructs include:

- Attitudes: This refers to the degree to which a person has a favourable or unfavourable evaluation of the behaviour of interest such as to use m-learning technologies. It entails a consideration of the outcomes of performing the behaviour of interest.

- Behavioural intention: This refers to the motivational factors that influence a given behaviour where the stronger the intention to perform the behaviour, the more likely the behaviour will be performed.

- Subjective norms: This refers to the belief about whether most people approve or disapprove of the behaviour. It relates to a person's beliefs about whether peers and people of importance to the person think he or she should engage in the behaviour, which relates to the self-efficacy.

- Social norms: This refers to the customary codes of behaviour in a group or people or in the context of institutions such as universities. Social norms are considered normative or standard as universities embark on implementation of m-learning to increase the effectiveness of teaching and learning process.

- Perceived power: This refers to the perceived presence of factors that may facilitate or impede performance of a 
behaviour. Perceived power contributes to a person's perceived behavioural control over each of those factors.

- Perceived behavioural control: This refers to a person's perception of the ease or difficulty of performing the behaviour of interest. Perceived behavioural control varies across situations and actions, which results in a person having varying perceptions of behavioural control depending on the situation. This construct of the theory was added later and created the shift from the TRA to the TPB.

The TPB assumptions as it relates to the present study are based on students' intention to use mobile devices such as smartphones, MP3 and MP4 devices, PDAs, tablet computers and other portable devices for m-learning. The TPB also explains a given (Yakasai \& Jusoh 2015):

$[B]$ ehaviour and the need to apprehend the factors of motivation for the adoption of m-learning. The theory of planned behaviour is a theory which predicts deliberate behaviour, because behaviour can be deliberative and planned. (p. 188)

The use of portable devices for m-learning is a well-planned learning outcome from both the institution and on the part of the students.

The institution must engage in series of planning activities before implementation whilst the students must be ready to adopt m-learning. Hence, the TPB theory has been effective in predicting acceptance and use of many different mobile technologies (Sentosa \& Mat 2012). The TPB has been used successfully to predict and explain a wide range of mobile technology adoption and intentions to use m-learning devices, amongst others.

Figure 1 has been applied to a multitude of behaviours to better understand how individuals behave in the way they do (Sommer 2011). Ajjan and Hartshorne (2008) used the theory of planned behaviour in a study to investigate faculty decisions to adopt Web 2.0 technologies and their findings inferred that subjective norm of students is a key factor that affects their acceptance. Similarly, a study of pre-service teachers, Teo and Lee (2010) using the TPB as a

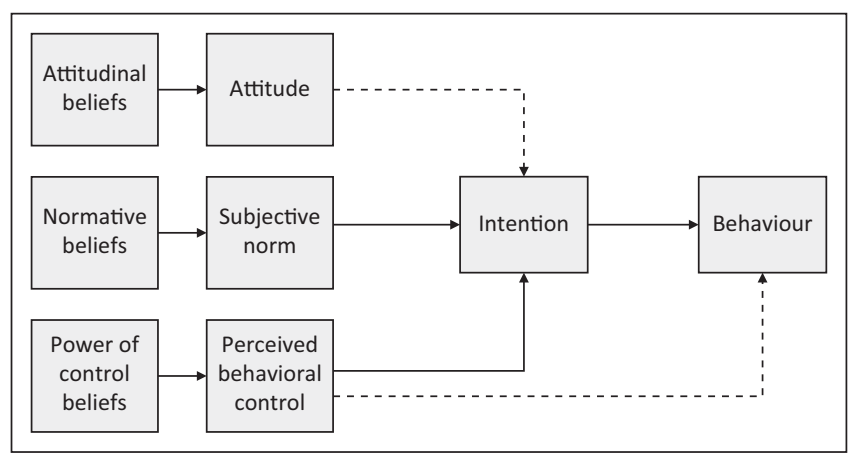

Source: Armitage, J. \& Conner, M., 2001, 'Efficacy of theory of planned behaviour', British Journal of Social Psychology 40(1), 471-499. https://doi.org/10.1348/014466601164939

FIGURE 1: Theory of planned behaviour. research model, found that attitude towards computer use and subjective norm have significant effect on behavioural intention to use technology; they further found that the same three constructs had explained about $40 \%$ of the variance in the behavioural intention to use technology. The TPB theory also relates to the variable of self-efficacy in this present study as it overlooked emotional factors such as threat, fear, mood and feelings that hinder self-efficacy of students in adopting and using mobile devices such as smartphones, MP3 and MP4 devices, PDAs, tablet computers and other portable devices for m-learning.

\section{Research objectives}

The main aim of this article is to assess students' perception and self-efficacy towards m-learning at the University of Zululand. The specific objectives of the study are as follow:

- ascertain students' perception of m-learning

- determine students' mobile self-efficacy in m-learning.

\section{Methodology}

The study is descriptive in nature and its purpose is to assess students' perception and self-efficacy towards mobile learning. As a result of the large population and financial constraints, the researchers administrated the surveys using the main campus only and thereby employed the stratified sampling technique breaking the population into four levels based on the faculties available in the main campus of the university. Thereafter, the random technique was used to select 50 students across each stratum (faculty). Therefore, a sample size of 200 students was used for this study. A structured questionnaire was used as the instrument for data collection. The questionnaire covered all the aspects of concern in this study. It was alienated into four sections. The first section consists of five items that represent the students' demographic data. The second section consists of seven items that represent the students' frequency of using social media applications. The third section of the survey consists of 10 items that represent students' perceptions of m-learning, whilst fourth section consists of six items that represent students' mobile self-efficacy. A five-point Likert scale, with strongly agree (5), agree (4), undecided (3), disagree (2) and strongly disagree (1) has been used to measure items in sections 3 and 4 . The return rate of questionnaire administered stood at $197(98.5 \%)$.

\section{Results and discussion}

This section provides analysis of the results obtained from the empirical survey and discussion of findings. The section covers students' demographic data, students' frequency of using social media applications, students' perceptions of m-learning and students' mobile self-efficacy. 
By analysing the demographic data (see Table 1), results indicated that female students represented 137 (69.5\%) as compared with male students 60 (30.5\%). With respect to age of the students, $149(75.6 \%)$ ranges between 18 and 22 whilst $45(22.8 \%)$ are in the ranges of 23 and 27 with only $3(1.5 \%)$ in the ranges of 28 and 32 . Therefore, a vast majority of the students are between the ages of 18 and 22, which is significant to this study as the largest demographic of mobile device users are 18-29 years old, which is also the typical age of college or university attendees (Cromptona \& Burkeb 2018).

By analysing students' frequency of using social media applications, results have shown that 192 (97.5\%) of the students always use WhatsApp whilst 187 (94.9\%) affirmed that they make use of Facebook always. Similarly, YouTube recorded 178 (90.1\%), whilst 139 (70.6\%) indicated that they always make use of Instagram. Other social media applications such as Twitter, LinkedIn and Skype were never used by majority of the students as indicated in Table 2.

Therefore, WhatsApp is the most popular social media applications as it is used by 192 (97.5\%) of the students.

TABLE 1: Characteristics of the students.

\begin{tabular}{lc}
\hline Characteristics & $\%$ \\
\hline Q1: Gender & 30.5 \\
Male & 69.5 \\
Female & \\
Q2: Age & 75.6 \\
18-22 & 19.3 \\
$23-27$ & 5.1 \\
$28-32$ & \\
\hline
\end{tabular}

TABLE 2: Students' frequency of using social media applications.

\begin{tabular}{llcccc}
\hline Number & Application & Always (\%) & Sometimes (\%) & Rarely (\%) & Never (\%) \\
\hline 1. & Facebook & 94.9 & 3.6 & 1.5 & 0 \\
2. & Twitter & 18.8 & 20.8 & 26.9 & 33.5 \\
3. & Instagram & 70.6 & 18.3 & 6.1 & 5.1 \\
4. & WhatsApp & 97.5 & 1.5 & 0.5 & 0.5 \\
5. & YouTube & 90.1 & 2.5 & 3.6 & 3.6 \\
6. & Linkedln & 10.7 & 16.8 & 21.3 & 51.3 \\
7. & Skype & 9.6 & 15.7 & 21.3 & 53.3 \\
\hline
\end{tabular}

The finding corroborates Al-Hunaiyyan et al.'s (2018) study on perceptions and challenges of m-learning in Kuwait. The study found out that majority of the students indicated that they always use WhatsApp, YouTube, Instagram and Twitter. These social mobile applications such as WhatsApp and Twitter amongst others commonly used by students enhance student-to-student and student-to-lecturer communication and had an increased opportunity for m-learning (Mayisela 2013).

The study sought to understand students' perceptions and self-efficacy towards m-learning. With respect to students' perception, the result indicated that students have positive perception towards m-learning, as indicated in Table 3. Findings revealed that majority 152 (77.2\%) of students agreed that learning by mobile helps them learn anytime and anywhere. The percentage of students' agreement that learning by mobile opens many ways to learn and provide various learning fields is 147 (74.6\%). Majority 133 (67.5\%) of students also affirmed that learning by mobile increases students' motivation to learn. Similarly, the result recorded $148(75.1 \%)$ agreement amongst students on 'having media files of my course content on my mobile helps me learn more'. Mobile helps to follow up on grades and student records got 154 (78.2\%) agreement. In addition, the result on 'learning by mobile is a good idea' is $132(67 \%)$ agreement. It is interesting that $98(49.7 \%)$ less than $50 \%$ of the respondents were in agreement on 'I feel satisfied if it were to impose the use of m-learning as a new learning tool'. Meaning that despite the acceptance of m-learning by the students, they do not want it to be imposed on them, maybe to complement the conventional learning medium. However, the agreement for 'the use of social media applications help in educational attainment' is high with $142(72.1 \%)$. Accordingly, 'the use of social media helps to strengthening the communication with others' recorded $162(82.2 \%)$ agreement from the students. However, majority $110(55.8 \%)$ of the students disagree with the assertion that the use of social media in education will cause social and family problems' thereby

TABLE 3: Students' perceptions of mobile learning.

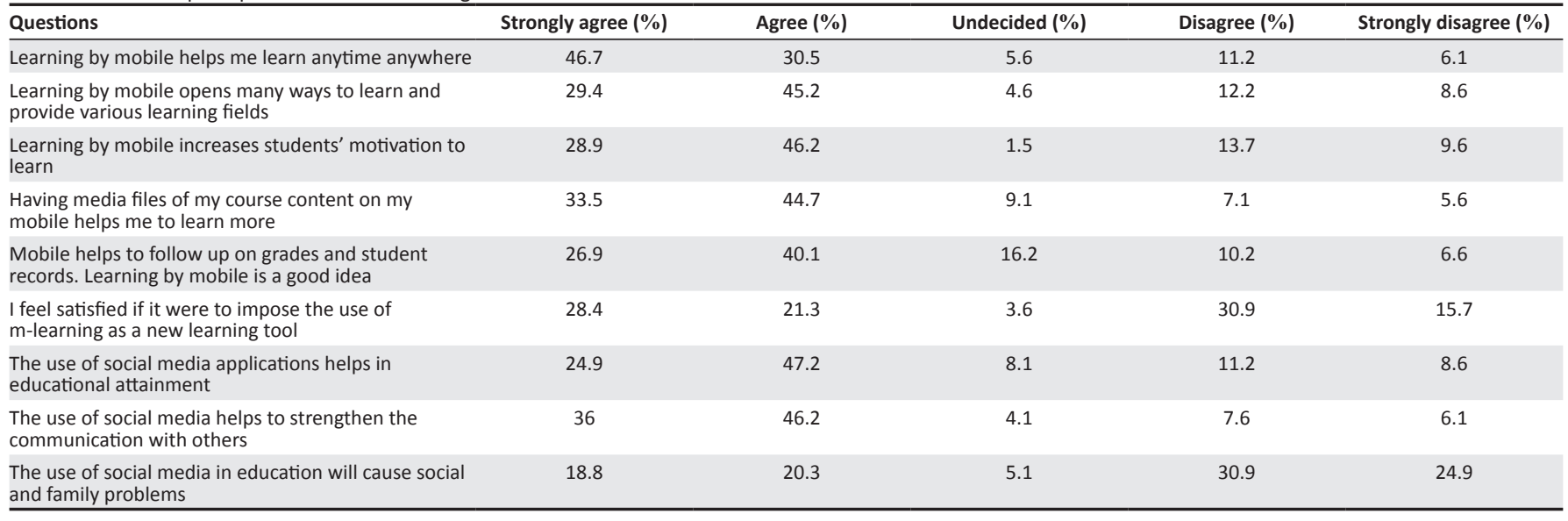


supporting m-learning. This finding contradicts AlHunaiyyan et al.'s (2018) study on perceptions and challenges of m-learning in Kuwait, where majority of the respondents were in agreement that 'the use of social media in education will cause social and family problems'.

The findings of this study indicate students' readiness for m-learning as perception determines use and influences how people behave (Jaradat 2014). Hence, if students perceive that m-learning has value to learning, they are likely to embrace the use of m-learning. Therefore, with research findings such as this, the university management should consider exploring the use of m-learning in educational context.

Besides students' perceptions of m-learning, students' mobile self-efficacy is an imperative contributor to students' readiness to adopt m-learning. It is of importance that students have confidence in order to ensure effective use of m-leaning devices. Six items were used in this section to measure students' mobile self-efficacy in an m-earning environment (Table 4). Findings indicated that the first item 'I would be able to use m-learning even if there was no one around to tell me how it works' received 103 (52.2\%) affirmative responses. The second item 'I would be able to use m-learning even if I had never been exposed to m-learning before' had 105 (53.3\%) agreement responses, likewise the third item 'I would be able to use m-learning only if I had seen someone else experience it before I try it myself' with 101 (51.2\%) agreement responses. Other items include 'I would be able to use m-learning if someone assisted me to get started' with 119 (60.4\%) affirmative responses, 'I would be able to use m-learning if I had first gone through a lesson on how to use it' recorded 138 (70.1) of agreement responses.

The sixth item 'I would be able to use m-learning if I could refer to someone for help if I face difficulties' had 123 (62.4\%) affirmative responses. The result indicated that students' self-rating is high but it is interesting to note that despite the students' confidence in using m-learning as indicated in the findings, they also need some form of assistance. From the findings, it can be inferred that the students believed that they would be able to use m-learning as indicated in items one and two. This finding corroborates existing studies.
Studies by Kenny et al. (2010), Tsai et al. (2010) and Mahat et al. (2012) also show that students have positive mobile selfefficacy in an m-learning environment. The last three items that require some form of assistance constituted the highest affirmative responses. Therefore, the findings suggest that the provision of technical assistance must be considered in the university implementation readiness of the institutions towards integrating m-learning into educational and academic programmes.

\section{Conclusion and recommendations}

For a proper implementation of m-learning, it is important to understand students' perception and self-efficacy towards $\mathrm{m}$-learning. The integration and use of m-learning in higher educational institutions is on the increase. Hence, students' readiness to embrace this new paradigm in education becomes very important. Before thinking of designing and implementing m-learning system, it is important to assess the perception and self-efficacy of future users regarding m-learning because its perception and self-efficacy influence their willingness and readiness to use the system. The results of this study indicated that students of the University of Zululand are ready to embrace m-learning. The results showed that students have positive perceptions towards m-learning and have a high level of confidence in using m-learning. Based on the findings, this study provides an insight into students' readiness to use m-learning at the University of Zululand. It will also assist the m-learning information communication technology unit of the university to understand the aspects to improve on and render technical supports as indicated in the findings.

Therefore, the study recommends that the university management fully integrate m-learning solutions to its academic programmes as students have shown their readiness in adopting m-learning. This will avail the University of Zululand the opportunity to enhance the quality of teaching and learning and ultimately enable the University of Zululand to achieve its desired learning outcomes. The study also recommends that the provision of technical assistance must be considered in the university implementation readiness of the institutions towards integrating m-learning into educational and academic programmes.

TABLE 4: Students' mobile self-efficacy.

\begin{tabular}{|c|c|c|c|c|c|}
\hline Questions & Strongly agree (\%) & Agree & Undecided (\%) & Disagree (\%) & Strongly disagree $(\%)$ \\
\hline $\begin{array}{l}\text { I would be able to use m-learning even when } \\
\text { there is no one to assist me }\end{array}$ & 21.3 & 30.9 & 4.6 & 25.4 & 17.8 \\
\hline $\begin{array}{l}\text { I would be able to use m-learning even if I am } \\
\text { not exposed to m-learning previously }\end{array}$ & 23.9 & 29.4 & 4.6 & 25.4 & 16.7 \\
\hline $\begin{array}{l}\text { I would be able to use m-learning only if I had } \\
\text { seen someone else practice it earlier }\end{array}$ & 22.8 & 28.4 & 5.1 & 24.4 & 19.3 \\
\hline $\begin{array}{l}\text { I would be able to use m-learning if someone } \\
\text { aided me to get started }\end{array}$ & 25.4 & 35 & 5.6 & 21.8 & 12.2 \\
\hline $\begin{array}{l}\text { I would be able to use m-learning if I had first } \\
\text { gone through a lesson on how to use it }\end{array}$ & 30.5 & 39.6 & 2.5 & 14.7 & 12.7 \\
\hline $\begin{array}{l}\text { I would be able to use m-learning if I could } \\
\text { consult someone for help during difficulties }\end{array}$ & 25.9 & 36.5 & 4.1 & 20.8 & 12.7 \\
\hline
\end{tabular}




\section{Acknowledgements Competing interests}

The author declares that he has no financial or personal relationships that may have inappropriately influenced him in writing this research article.

\section{Author's contribution}

I.O. is the sole author of this research article.

\section{Ethical considerations}

This article followed all ethical standards for research without direct contact with human or animal subjects.

\section{Funding information}

This research received no specific grant from any funding agency in the public, commercial or not-for-profit sectors.

\section{Data availability}

The datasets generated during the current study are not publicly available because of this being a subset of a broader study, which is currently being completed but are available from the corresponding author on reasonable request.

\section{Disclaimer}

The views and opinions expressed in this article are those of the author and do not necessarily reflect the official policy or position of any affiliated agency of the author.

\section{References}

Ajjan, H. \& Hartshorne, R., 2008, 'Investigating faculty decisions to adopt Web 2.0 technologies: Theory and empirical tests', The Internet and Higher Education 11(2), 71-80. https://doi.org/10.1016/j.iheduc.2008.05.002

Al-Emran, M., Elsherif, H. \& Shaalan, K., 2016, 'Investigating attitudes towards the use of mobile learning in higher education', Computers in Human Behavior 56 , 93-102. https://doi.org/10.1016/j.chb.2015.11.033

Al-Hunaiyyan, A., Alhajri, R. \& Al-Sharhan, S., 2018, 'Perceptions and challenges of mobile learning in Kuwait', Journal of King Saud University-Computer and Information Sciences 30(1), 279-289. https://doi.org/10.1016/j.jksuci.2016. 12.001

Al-Jarrah, J.M., Talafhah, R.H. \& Al-Jarrah, T.M., 2019, 'ESL teacher perceptions of using educational mobile applications to develop the language skills of ESL elementary school students', European Journal of Foreign Language Learning 4(1), 65-86. https://doi.org/10.5281/zenodo.2257442

Al-Shehri, S., 2012, 'Contextual language learning: The educational potential of mobile technologies and social media', Doctoral dissertation, The University of Queensland.

Alzahrani, A., Alalwan, A. \& Sarrab, M., 2014, 'Mobile cloud computing: Advantage, disadvantage and open challenge', Proceedings of the 7th Euro American on Telematics and Information Systems, (EATIS 2014), Valparaiso, pp. 1-4.

Armitage, J. \& Conner, M., 2001, 'Efficacy of theory of planned behaviour', British Journal of Social Psychology 40(1), 471-499. https://doi.org/10.1348/ 014466601164939

Chaka, J. \& Govender, I., 2017, 'Students' perceptions and readiness towards mobile learning in colleges of education: A Nigerian perspective', South African Journal of Education 37(1), 1-12. https://doi.org/10.15700/saje.v37n1a1282

Chen, B., Seilhamer, R., Bennett, L. \& Bauer, B., 2015, Students' mobile learning practices in higher education, viewed 31 February 2020, from http://ereducause. practices in higher education, viewed 31 rebruary 2020 , from hittp://er.educause. multiyear-study.

Cheon, J., Lee, S., Crooks, S.M. \& Song, J., 2012, 'An investigation of mobile learning readiness in higher education based on the theory of planned behavior', Computers \& Education 59(3), 1054-1064. https://doi.org/10.1016/j.compedu. 2012.04.015
Cromptona, H. \& Burkeb, D., 2018, 'The use of mobile learning in higher education: A systematic review', Computers \& Education 123(1), 53-64. https://doi. org/10.1016/j.compedu.2018.04.007

De Pablos, P.O., Tennyson, R.D. \& Lytras, M.D., 2015, Assessing the role of mobile technologies and distance learning in higher education, IGI-Global, Hershey, PA.

Enriquez, A.G., 2010, 'Enhancing student performance using tablet computers', College Teaching 58(3), 77-84. https://doi.org/100.1080/87567550903263859

Erkollar, A. \& Oberer, B.J., 2012, 'Anytime. Everywhere. Mobile learning in higher education: Creating a GIS course', in Computer applications for database, education, and ubiquitous computing, 352(1), 31-37, Springer-Verlag, Berlin, Heidelberg.

Hamidi, H. \& Chavoshi, A., 2018, 'Analysis of the essential factors for the adoption of mobile learning in higher education: A case study of students of the University of Technology', Telematics and Informatics 35(4), 1053-1070. https://doi. org/10.1016/j.tele.2017.09.016

Hung, J.L. \& Zhang, K., 2012, 'Examining mobile learning trends 2003-2008: A categorical meta-trend analysis using text mining techniques', Journal of Computing in Higher Education 24(1), 1-17. https://doi.org/10.1007/s12528011-9044-9

Hwang, G.J. \& Chang, H.F., 2011, 'A formative assessment-based mobile learning approach to improving the learning attitudes and achievements of students', Computers and Education 56(4), 1023-1031. https://doi.org/10.1016/j. compedu.2010.12.002

Hwang, G.J. \& Tsai, C.C., 2011, 'Research trends in mobile and ubiquitous learning: A review of publications in selected journals from 2001 to 2010', British Journal of Educational Technology 42(4), E65-E70. https://doi.org/10.1111/j.1467-8535. 2011.01183.x

Jaradat, R.M., 2014, 'Students' attitudes and perceptions towards using m-learning for French language learning: A case study on Princess Nora University', International Journal of Man-Machine Studies 2(1), 33-44. https://doi. org/10.12785/ijlms/020103

Jou, M., Tennyson, R., Wang, J. \& Huang, S., 2016, 'A study on the usability of E-books and APP in engineering courses: A case study on mechanical drawing', Computers \& Education 92-93(1), 181-193. https://doi.org/10.1016/j.compedu.2015.10.004

Keengwe, J. \& Maxfield, M.B., 2015, Advancing higher education with mobile learning technologies: Cases, trends and inquiry-based methods, IGI Global, Hershey, PA.

Kenny, R.F., Park, C.L., Van Neste-Kenny, J.M. \& Burton, P.A., 2010, 'Mobile self efficacy in Canadian nursing education programs', Proceedings of m-Learn 2010, the 9th World Conference on Mobile Learning, Valletta, Malta, viewed 10 March 2020, from http://hdl.handle.net/2149/2767.

Kukulska-Hulme, A., 2014, 'Mobile, wearable, companionable: Emerging technological challenges and incentivesfor learning', Minutes of the 2nd Meeting on Games and Mobile Learning, Education Research Center (CIEd), Madrid, Spain, 28 February 02 March, pp. 12-15.

Lee, J. \& Mendlinger, S., 2011, 'Perceived self-efficacy and its effect on online learning acceptance and student satisfaction', Journal of Service Science and Management 4(1), 243-252. https://doi.org/10.4236/jssm.2011.43029

Li, L., 2010, 'A critical review of technology acceptance literature', The Southwest Decision Sciences Institute Annual Meeting (SWDSI), Dallas, TX, 03-05 March.

Liaw, S.S., Hatala, M. \& Huang, H.M., 2010, 'Investigating acceptance of mobile learning to assist individual knowledge management: Based on Activity Theory approach', Computers \& Education 54(2), 446-454. https://doi.org/10.1016/j. compedu.2009.08.029

Mahat, J., Ayub, A. \& Wong, S., 2012, 'An assessment of students' mobile self-efficacy, readiness and personal innovativeness towards mobile learning in higher education in Malaysia', Procedia - Social and Behavioral Sciences 64, 284-290. https://doi.org/10.1016/j.sbspro.2012.11.033

Mayisela, T., 2013, 'The potential use of mobile technology: Enhancing accessibility and communication in a blended learning course', South African Journal of Education 33(1), 1-18. https://doi.org/10.15700/saje.v33n1a629

Menekse, M., Anwar, S. \& Purzer, S., 2018, 'Self-efficacy and mobile learning technologies: A case study of CourseMIRROR', in C. Hodges (eds.), Self-efficacy in instructional technology contexts, pp. 57-74, Springer, London. https://doi. org/10.1007/978-3-319-99858-9

Moreira, F., Pereira, C., Durão, N. \& Ferreira, M., 2018, 'A comparative study about mobile learning in Iberian Peninsula Universities: Are professors ready', Telematics and Informatics 35 (1), 979-992. https://doi.org/10.1016/j.tele.2017.09.010

Sarrab, M., 2015, 'M-learning in education: Omani Undergraduate students' perspective', Procedia - Social and Behavioral Sciences 176, 834-839. https://doi. org/10.1016/j.sbspro.2015.01.547

Sentosa, I. \& Mat, N.K., 2012, 'Examining a theory of planned behaviour (TPB) and technology acceptance model (TAM) in Internet purchasing using structural equation modelling', Journal of Arts, Science and Commerce 3(2), 62-77.

Sharma, H. \& Nasa, G., 2014, 'Academic self-efficacy: A reliable predictor of educational performances', British Journal of Education 2(3), 57-64, viewed 22 February 2020, from http://www.eajournals.org/wp-content/uploads/AcademicSelf-Efficacy-A-Reliable-Predictor-of-Educational-Performances1.pdf.

Sommer, L., 2011, 'The theory of planned behaviour and the impact of past behaviour', International Business and Economics Research Journal 10(1), 91-110. https:// doi.org/10.19030/iber.v10i1.930

Tana, X. \& Aib, B., 2011, 'The issues of cloud computing security in high-speed railway', International Conference on Electronic \& Mechanical Engineering and Information Technology, Heilongjiang, China, 12-14 August. 
Teo, T. \& Lee, C., 2010, 'Explaining the intention to use technology among student teachers', Campus-Wide Information Systems 27(2), 60-67. https://doi. teachers', Campus-Wide Inform

Tsai, P.-S., Tsai, C.-C. \& Hwang, G.-H., 2010, 'Elementary school students' attitudes and self-efficacy of using PDAs in a ubiquitous learning context', Australasian Journa of Educational Technology 26(3), 279-380. https://doi.org/10.14742/ajet.1076

Yakasai, A.B.M. \& Jusoh, W.J.W., 2015, 'Testing the Theory of Planned Behavior in determining intention to use digital coupon among university students', Procedia Economics and Finance 31, 186-193. https://doi.org/10.1016/S2212-5671(15)01145-4
Yorganci, S., 2017, 'Investigating students' self-efficacy and attitudes towards the use of mobile learning', Journal of Education and Practice 8(6), 181-185.

Zheng, J., Li, S. \& Zheng, Y., 2017, 'Students' technology acceptance, motivation and self-efficacy towards the eSchoolbag: An exploratory study', International Journal for Infonomics 10(3), 1350-1358. https://doi.org/10.20533/iji.1742.4712. 2017.0165

Zidoun, Y., Arroum, F.E., Talea, M. \& Dehbi, R., 2016, 'Students' perception about mobile learning in Morocco: Survey analysis', International Journal of Interactive Mobile Technologies 10, 80-84. https://doi.org/10.3991/ijim.v10i4.5947 